\title{
HUBUNGAN ANTARA PERSEPSI LANSIA DENGAN KEAKTIFAN DATANG KE POSYANDU DI POLINDES LARANGAN KECAMATAN LARANGAN KABUPATEN PAMEKASAN
}

Sari Pratiwi Apidianti, Program Studi DIII Kebidanan Universitas Islam Madura

e-mail: saripratiwie86@gmail.com

\section{ABSTRACT}

The elderly Posyandu is a health service for the elderly at village or kelurahan level in the working area of the puskesmas. Based on preliminary data obtained in the prohibition village, from 20 elderly it was found that almost half of the elderly were inactive came to posyandu (43.48\%). The purpose of this study was to determine the relationship of perception with the liveliness of the elderly came to posyandu in the prohibition village in the work area of Puskesmas Larangan Pamekasan District.

Research design with Analytic Case Control where the population is 552 elderly. The sample in this study was obtained from 227 elderly people through Systematic Sampling. The independent variable in this study is the perception of the elderly, while the dependent variable is the elderly activity that comes to posyandu

The result of statistical test $\times 2$ count $=67.45$ and $\times 2$ table $=3,841$, because $\times 2$ tel $>\times 2$ table than $\mathrm{HI}$ is accepted and $\mathrm{HO}$ is rejected which means that "relationship between perception with older activity comes to posyandu in Polindes Larangan In working area of Puskesmas Larangan Subdistrict Larangan Pamekasan Regency

Health professionals are expected to be more active in guiding, assisting and guiding the elderly in posyandu activities, and do not forget to give motivation and to provide information about older posy options in the elderly.

Keyword: Perception, Elderly Activity

\section{PENDAHULUAN}

Berdasarkan demografi, diperoleh hasil sensuspenduduk tahun 1971 di Indonesia diperoleh data bahwa yang berada di usia 60 tahun ke atas sebesar 5,3 juta atau $4,5 \%$ jumlah total penduduk. Tiap 10 tahun Terjadi peningkatan 3-4 juta penduduk lansia (Hardywinato \& Setiabudhi, 2005). Adanya Perubahan penduduk pada kelompok lanjut usia(lansia) yang berhubungan dengan status kesehatan lansia yang lebih terjamin, dengan ini diharapkan agara usia harapan hidup lansia lebih tinggi dibanding masa sebelumnya.

Menjadi manusia lansia ( usia lanjut) merupakan peristiwa yang alamiah dan pasti akan dialami oleh semua orang dan sehat di usia lanjut adalah suatu rahmat (Mangoenprasodjo, 2008). Perubahan yang terjadi pada lansia diantaranya penuaan di semua sistem tubuh manusia ditandai dengan kemunduran sistem dalam waktu yang tidak sama . (Pudjiastuti, 2003). Pertambahan usia pada lansia akan berpengaruh terhadap kondisi fisik dan mental, termasuk kontak sosial otomatis berkurang. kesehatan pada lansia seharusnya lebih diperhatikan karena fungsi anatomi dan organ-organ tubuh lainnya sudah tidak sesempurna seperti ketika berusia muda, selain itu Hubungan kemasyarakatan juga tidak kalah pentingnya karena hal ini akan berpengaruh terhadap bagaimana cara merawat diri sendiri semakin menurun kualitas dan kuantitasnya (Nurkusuma, 2008). Selain mengalami penurunan tingkat fertilitas, akan terjadi perubahan yang riil terhadap struktur umur. Dengan meningkatnya umur lansia maka hal ini akan menambah proporsi danj umlah penduduk usia tua, dan jumlah penduduk usia sangat tua.

Partisipasi masyarakat merupakan komponen utama keberhasilan program. Oleh karena itu partisipasi masyarakat perlu di usahakan keaktifannya sedini mungkin dalam pelaksanaan program, untuk itu pemerintah sangat berharap semua masyarakat dapat ikut berpartisipasi aktif dalam pelaksanaan program untuk kesehatan terutama program posyandu, yaitu seharusnya semua lansia datang ke posyandu dengan frekuensi minimal 8 kali pertahun dan cakupan target adalah $80 \%$ (Depkes RI, 2003:10). Tapi kenyataannya cakupan di Desa Larangan Dalam pada tahun 2011 masih mencapai 43,48 \%.

Kondisi ini di pengaruhi oleh beberapa faktor yaitu Kurangnya pengetahuan lansia tentang manfaat posyandu lansia, jarak antara lokasi posyandu dengan rumah lansia berpengaruh terhadap kurangnya dukungan 
keluarga untuk mengantar lansia untuk datang ke posyandu, persepsi lansia terhadap kegiatan posyandu, dapat menyebabkan lansia tidak aktif datang ke posyandu.

Studi pendahuluan yang di lakukan pada 20 lansia yang di peroleh melalui wawancara pada bulan desember tahun 2011 yang tidak aktif datang ke posyandu, dari 20 orang di dapatkan 12 orang (12\%) lansia tidak datang ke posyandu karena mereka beranggapan meski tidak datang ke posyandu mereka akan tetap sehat, sehingga posyandu di anggap tidak begitu berpengaruh terhadap kesehatan mereka, 6 orang (6\%) mengatakan tidak datang karena tidak ada keluarga yang mengantar, dan 2 orang (2\%) lagi mengatakan karena tempatnya jauh dari tempat di laksanakannya posyandu tersebut. Kondisi ini menggambarkan bahwa masih banyak lansia yang memiliki persepsi yang salah tentang posyandu lansia.

Akibatnya lansia tidak datang ke posyandu yaitu tidak dapat mendiagnosa dini tentang kesehatan lansia, dan sakit yang dimiliki lansia tersebut tidak cepat tertangani, karena lanjut usia merupakan kelompok khusus masyarakat yang mempunyai karakteristik tertentu dan rentan terhadap penyakit dikarenakan menurunnya kemampuan fisik dan penurunan kekebalan tubuh sehingga perlu mendapat perhatian khusus terutama dalam masalah kesehatan.

Manfaat diadakannya posyandu lansia adalah tidak lain untuk Meningkatkan jangkauan pelayanan kesehatan lansia sehingga kebutuhan lansia dapat terpenuhi dengan peran serta masyarakat dalam hal komunikasi antara masyarakat usia lanjut. Dari masalah diuraikan di atas, di butuhkan solusi mengenai hal ini upaya untuk mengatasi ketidakaktifan lansia datang ke posyandu diantaranya yaitu meningkatkan pengetahuan lansia seperti memberikan penyuluhan terhadap manfaat diadakannya posyandu.

Pentingnya Peran dari Keluarga yaitu dapat dibuktikan dengan mengantarkan lansia untuk datang ke posyandu dan selalubersedia mendengarkan apa yang dikeluhkan serta mencari penanganan terhadap apa yang sedang dirasakan, Peran instansi kesehatan terdekat juga sangat penting dalam perawatan pada lansia, yaitu dengan cara penyuluhanpenyuluhan tentang cara perawatan pada lansia dan mengenali masalah-masalah yang terjadi pada lansia. Untuk itu lansia harus memeriksakan kesehatannya sesuai saran petugas kesehatan, dengan ini pemerintah mengadakan program pembinaan ysng berhubungan dengan kesehatan usia lanjut yaitu posyandu lansia untuk mengetahui perkembangan kesehatan lansia tersebut, dengan adanya posyandu lansia di harapkan lansia dapat mengikuti posyandu di desanya.

Berdasarkan data diatas peneliti berkeinginan untuk meneliti "hubungan antara persepsi lansia dengan keaktifan lansia datang ke posyandu". Karena keterbatasan waktu dan luasnya masalah maka peneliti hanya membatasi pada hubungan antara persepsi dengan keaktifan lansia datang ke posyandu.

\section{METODE PENELITIAN}

Penelitian ini bersifat analitik korelasi dengan metode Case Control yaitu menemukan fakta Kemudian dianalisis antara persepsi dengan keaktifan lansia datang ke Posyandu dengan mengetahui faktor resiko dengan pendekatan retrospectif menggunakan uji statistik. (Notoatmodjo, 2005:148). Variable Independen dalam penelitian ini adalah persepsi variabel dependen dalam penelitian ini adalah keaktifan lansia datang ke posyandu. Sampel yang digunakan adalah lansia berjumlah 227 orang di Polindes Larangan dengan tekhnik probability sampling.

Tempat penelitian di Polindes Larangan Dalam Wilayah kerja Puskesmas Larangan Dalam. Analisa data pada proses ini peneliti melakukan distribusi frekuensi dengan menggunakan teknik analisis univariate yaitu mendeskripsikan variabel independen (bebas) danvariabel dependen (terikat) serta analisis bivariat dilakukan terhadap persepsi dan keaktifan lansia datang ke Posyandu kemudian dilakukan Ujistatistik Chi Square.

\section{HASIL PENELITIAN}

1. Karakteristik Responden berdasar Umur

\begin{tabular}{ccc}
\hline Umur (tahun) & Frekuensi & Persentase $(\%)$ \\
\hline $45-59$ tahun & 121 & 53.30 \\
60-74 tahun & 65 & 28.63 \\
$75-90$ tahun & 27 & 11.91 \\
$\geq 90$ tahun & 14 & 6.17 \\
\hline Total & 227 & 100
\end{tabular}

Tabel 1 menunjukkan responden berumur 4559 tahun sebanyak 121 orang (53.30\%).

2. Karakteristik Responden berdasarkan Pekerjaan

\begin{tabular}{ccc}
\hline Pekerjaan & Frekuensi & Persentase \\
\hline Petani & 125 & 55.07 \\
IRT & 78 & 34.36 \\
Swasta & 24 & 10.57 \\
\hline Total & 227 & 100 \\
\hline
\end{tabular}


Tabel 2. Menunjukkan Lansia sebagian besar $(55.07 \%)$ adalah sebagai petani yaitu 125 orang.

3. Karakteristik Responden berdasarkan Pendidikan

\begin{tabular}{ccc}
\hline Pendidikan & Frekuensi & Persentase \\
\hline Dasar & 130 & 57.26 \\
Menengah & 85 & 37.44 \\
Tinggi & 12 & 5.28 \\
\hline Total & 227 & 100 \\
\hline
\end{tabular}

Tabel 3 menunjukkan Lansia sebagian besar $(57.26 \%)$ berpendidikan dasar sebanyak 130 orang

4. Karakteritik Responden berdasar Persepsi Berdasarkan tabel 4 menunjukkan bahwa dari 227 responden, sebagian besar $(59.91 \%)$ bersikap negatif yaitu sebanyak 136 orang.

\begin{tabular}{ccc}
\hline Persepsi & Frekuensi & Persentase \\
\hline Positif & 91 & 40.08 \\
Negatif & 136 & 59.91 \\
\hline Total & 227 & 100 \\
\hline
\end{tabular}

Tabel 4 menunjukkan sebagian besar (59.91\%) bersikap negatif yaitu sebanyak 136 orang.

5. Karakteristik Responden berdasarkan Keaktifan Lansia Datang Ke Posyandu

\begin{tabular}{ccc}
\hline Keaktifan Lansia & Frekuensi & Persentase \\
\hline Aktif & 95 & 41.85 \\
Tidak aktif & 132 & 58.14 \\
\hline Total & 227 & 100 \\
\hline
\end{tabular}

Tabel 5 menunjukkan sebagian besar lansia tidak aktif datang ke posyandu ( $58,14 \%$ ) yaitu sebanyak132 orang

6. Tabulasi silang antara persepsi Dan Keaktifan Lansia datang ke posyandu

\begin{tabular}{ccccccc}
\hline \multirow{2}{*}{ Persepsi } & \multicolumn{4}{c}{ Keaktifan Lansia } & \multirow{2}{*}{ Total } \\
\cline { 2 - 5 } & \multicolumn{2}{c}{ Aktif } & \multicolumn{3}{c}{ Tidak aktif } & \\
\cline { 2 - 6 } & $(\mathrm{n})$ & $(\%)$ & $(\mathrm{n})$ & $(\%)$ & $(\mathrm{n})$ & $(\%)$ \\
\hline Positif & 68 & 74.72 & 23 & 25.27 & 91 & 100 \\
negatif & 27 & 19.11 & 109 & 80.14 & 136 & 100 \\
\hline Total & 95 & 41.85 & 132 & 58.14 & 227 & 100 \\
\hline
\end{tabular}

Tabel 6 menunjukkan bahwa responden yang mempunyai persepsi positif tetapi aktif sebagian besar $(74.72 \%)$ sebanyak 68 orang, sementara untuk responden yang mempunyai persepsi negatif tetapi tidak aktif hampir seluruhnya $(80.14 \%)$ sebanyak 109 orang,

\section{PEMBAHASAN}

\section{Persepsi Lansia tentang Posyandu}

Berdasarkan hasil penelitian didapatkan data bahwa sebagian besar lansia mempunyai persepsi negatif tentang posyandu sebanyak 136 lansia (59.91\%) dari 227 lansia dan hampir setengahnya mempunyai persepsi positif tentang posyandu lansia yaitu 91 lansia $(40.08 \%)$.

Dari kejadian diatas menunjukkan bahwa masih banyak lansia yang mempunyai persepsi negatif tentang posyandu lansia. $\mathrm{Hal}$ ini dipengaruhi oleh beberapa faktor yaitu pendidikan, informasi yang kurang, serta budaya yang melekat pada kehidupan lansia itu sendiri. Pendidikan yang dimiliki oleh lansia di desa larangan sebagian besar lansia tergolong masih rendah yaitu masih banyak lansia yang baru tamat SD dan SMP. Tingkat pendidikan yang rendah akan berpengaruh pada seseorang dalam merespon tentang sesuatu yang datang dari luar dan menghambat perkembangan persepsi seseorang terhadap nilai atau informasi yang baru diperkenalkan. Semakin tinggi pendidikan seseorang maka dalam memberikan respon lebih rasional.

Sesuai dengan teori Notoatmodjo (2003), yang menyatakan bahwa kemampuan yang terdapat pada diri seseorang dapat dipengaruhi oleh faktor pendidikan yang dia miliki. Hal ini berpengaruh terhadap pola pikir. Sehingga ketika seorang mempunyai pengetahuan yang luas maka semakin mudah menjabarkan sesuatu yang disampaikan.

Banyaknya informasi yang diterima oleh lansia akan mengakibatkan lansia tersebut memberikan persepsi positif terhadap posyandu lansia yang diberikan dalam kegiatan posyandu lansia, sehingga lansia dapat termotivasi dan aktif dalam mengikuti kegiatan posyandu. Sebaliknya informasi yang kurang menyebabkan lansia meniru pemikiran yang ada disekitarnya walaupun pemikiran tersebut tidak sesuai dengan kebenaran, karena masyarakat di desa Larangan Dalam sangat sulit mendapatkan informasi yang baru diperkenalkan. Hal tersebut menjadi dasar masih banyak lansia yang memiliki pemikiran yang salah tentang posyandu lansia.

Pernyataan ini diperkuat dengan adanya teori Notoatmodjo (2003) yang menyatakan bahwa lingkungan sosial seseorang memberikan pengaruh terhadap persepsi seseorang. Hal ini juga didukung oleh teori yang diungkapkan Mulyana, 2005 yang menyatakan bahwa Persepsi adalah proses menangkap arti obyek-obyek sosial dan 
kejadian-kejadian yang kita alami dalam lingkungan kita, manusia secara umum menerima informasi dari lingkungan lewat proses yang sama, oleh karena itu dalam memahami persepsi harus ada proses dimana ada informasi yang diperoleh lewat memory organisme yang hidup. Fakta ini memudahkan peningkatan persepsi individu, adanya stimulus yang mempengaruhi individu yang mencetus suatu pengalaman dari organisme, sehingga timbul berpikir yang dalam proses perceptual merupakan proses yang paling tinggi.

\section{Keaktifan Lansia datang ke posyandu}

Berdasarkan data yang diperoleh dari penelitian di polindes Larangan Dalam sebagian besar lansia tidak aktif datang ke posyandu yaitu 132 lansia (58.14\%). Sedangkan hampir setengahnya lansia yang aktif datang ke posyandu yaitu 95 orang $(41.85 \%)$.

Dari data tersebut menunjukkan bahwa masih banyak lansia yang tidak aktif datang ke posyandu. Hal ini dipengaruhi oleh beberapa faktor yaitu Umur lansia. Dari tabel 4.1 didapatkan bahwa sebagian besar lansia berumur 45-59 sebanyak 121 lansia yaitu $(53,30 \%)$. Umur lansia yang semakin tua akan mempengaruhi terhadap daya tangkap dan pola pikir lansia, karena pada masa tersebut terjadi penurunan fungsi tubuh dan tidak akan mengalami perkembangan lagi sehingga tidak ada peningkatan kualitas fisik, Menurut Hardywinoto (2005), menyatakan bahwa pada umur tersebut sangat butuh sarana pelayanan kesehatan terkait penurunan berbagai fungsi dan kelemahan. Keaktifan juga di pengaruhi oleh pekerjaan lansia. Dari tabel 4.2 didapatkan bahwa sebagian besar lansia bekerja sebagai petani sebanyak 125 orang (55,07\%). Pekerjaan lansia sebagai petani sangat berpengaruh terhadap keaktifan lansia, karena bekerja sebagai petani yang cenderung sibuk dan menghabiskan waktu yang banyak diluar rumah, sehingga lansia tidak mempunyai waktu untuk aktif datang ke posyandu. Menurut Landy dan Conte (2007) kesibukan seseorang diluar rumah akibat tuntutan pekerjaan, menyebabkan perhatian terhadap kesehatan berkurang bahkan hampir tidak ada. Pendidikan juga berpengaruh terhadap keaktifan lansia untuk datang ke posyandu. Dari tabel 4.3 di dapatkan bahwa sebagian besar lansia berpendidikan dasar sebanyak 130 orang $(57,26 \%)$.

Semakin tinggi pendidikan seorang lansia biasanya semakin mudah pula dalam menerima suatu informasi, khususnya dalam bidang kesehatan. Hal ini dibuktikan dalam menjaga kesehatan akan sangat diperhatikan. Termasuk datang ke posyandu secara teratur. Begitu pula sebaliknya, apabila lansia tersebut berpendidikan rendah maka hal ini akan berpengaruh terhadap penerimaan informasi yang diperoleh, baik langsung mapun secara tidak langsung. Menurut Nursalam (2003), Pendidikan merupakan stimulus yang diberikan oleh seseorang terhadap perkembangan orang lain baik dalam bentuk pembelajaran, keterampilan dan kebisaan menuju kearah suatu cita-cita. Pentingnya Peran serta dari masyarakat untuk mengaktifkan posyandu, seperti peran serta bidan, kader, perangkat desa serta tokoh masyarakat sehingga lansia dapat aktif datang ke posyandu.

Seperti halnya menurut buku pedoman kerja fisik yang dikutip dari www. Intanghina, wordpress. Com. 2008. Akses pada tanggal 2 desember 2008, mengemukakan bahwa dalam pengembangan peran serta atau keaktifan dalam suatu kegiatan masyarakat dalam mengikuti suatu program dapat mencapai maximal, penggalangan dukungan penentu kebijakan, pemimpin wilayah berbagai organisasi kesehatan, dukungan dari keluarga, persiapan petugas kesehatan dalam melakukan suatu kegiatan masyarakat. serta yang paling penting jika semua program sudah berjalan dengan lancar maka perlu adanya pengembangan dan pelestarian kegiatan kesehatan, sehingga kegiatan yang sudah terlaksana dapat berjalan terus menerus. Hal ini juga di dukung oleh Suryani (2003), yang menyatakan bahwa seseorang dapat dikatakan aktif apabila seseorang tersebut teratur dan dapat terlibat dalam suatu kegiatan

\section{Hubungan persepsi Dengan Keaktifan Lansia Datang Ke Posyandu.}

Berdasarkan hasil penelitian bahwa responden yang mempunyai persepsi positif 91 (40.08\%) Responden tidak aktif ke posyandu, sedangkan responden yang mempunyai 
persepsi negatif 136 (59.91\%) responden tidak aktif ke posyandu. Berdasarkan hasil uji statistik chi- squere antara persepsi dengan keaktifan lansia datang ke posyandu diperoleh X2 hitung 67.49 dan X2 table 3,841 karen X2 hitung > X2 tabel, maka $\mathrm{H} 1$ diterima yang artinya ada "Hubungan antara persepsi dengan keaktifan lansia datang ke posyandu di Polindes Larangan Dalam wilayah kerja Puskesmas Larangan Kabupaten Pamekasan".

Berdasarkan Hasil tabulasi silang dapat disimpulkan bahwa persepsi dapat memberikan pengaruh pada keaktifan lansia datang ke posyandu, karena persepsi yang positif sangat mendukung Lansia dalam mensukseskan posyandu Lansia. Sedangkan persepsi negatif yang tertanam dalam diri Lansia akan menyebabkan Lansia tidak akan aktif dalam posyandu. Guna merangsang kunjungan usia lanjut ke posyandu perlu pemberian makanan tambahan (PMT) penyuluhan serta sebagai media konseling gizi pada usia lanjut digunakan food model, leaflet dan buklet serta melibatkan keluarga dalam memotivasi usia lanjut untuk melaksanakan perilaku yang dianjurkan.

Menurut Mulyana ( 2005 ) persepsi merupakan suatu kegiatan untuk menafsirkan informasi sensorik yang berfunsi memberikan gambaran serta pemahaman tentang lingkungan. Sebagai manusia dalam hal penerimaan informasi akan melalui proses yang sama, oleh karena itu dalam memahami persepsi harus ada proses dimana ada informasi yang diperoleh melalui penglihatan, penciuman, pendengaran.

\section{KESIMPULAN}

Berdasarkan analisa dan pembahasan dapat disimpulkan bahwasanya terdapat hubungan persepsi Dengan Keaktifan Lansia Datang Ke Posyandudi desa Larangan Wilayah kerja Pukesmas Larangan Kabupaten Pamekasan.

\section{DAFTAR PUSTAKA}

Aritonang, Irianto, 2005 Aplikasi Statistika, Yogyakarta, Media Pressindo

Arikunto, Suharsini, 2006. Prosedur penelitian suatu pendekatan praktek. Yogyakarta : PT Rineka. Cipta
Lasma, 2007. Pedoman Praktis Bidan senam usia lanjut. Jakarta : EGC

Maramis, 1998. Persepsi dan Perilaku Kesehatan. Jakarta : Rineka Cipta

Mulyana, 2005. Konsep dan pengertian persepsi, Jakarta: Salemba medika

Nursalam, (2011).konsep dan penerapan metode penelitian ilmu keperawatan. Jakarta : Salemba Medika

Walgito, 2003. Psikologi Sosial. edisi kedua. Bandung : PT Refika Aditama

Bimo. 2011 . Pengantar Psikologi Umum. Yogyakarta : Andi Offset

Wilson D, 2000. Faktor-faktor persepsi Jakarta : Kelompok Gramedia 